\title{
Front Matter: Volume 7921
}

, "Front Matter: Volume 7921," Proc. SPIE 7921, Laser-based Micro- and Nanopackaging and Assembly V, 792101 (18 March 2011); doi:

$10.1117 / 12.890190$

SPIE. Event: SPIE LASE, 2011, San Francisco, California, United States 


\title{
PROCEEDINGS OF SPIE
}

\section{Laser-based Micro- and Nanopackaging and Assembly $V$}

\author{
Wilhelm Pfleging \\ Yongfeng Lu \\ Kunihiko Washio \\ Jun Amako \\ Willem Hoving \\ Editors
}

25-27 January 2011

San Francisco, California, United States

Sponsored and Published by

SPIE 
The papers included in this volume were part of the technical conference cited on the cover and title page. Papers were selected and subject to review by the editors and conference program committee. Some conference presentations may not be available for publication. The papers published in these proceedings reflect the work and thoughts of the authors and are published herein as submitted. The publisher is not responsible for the validity of the information or for any outcomes resulting from reliance thereon.

Please use the following format to cite material from this book:

Author(s), "Title of Paper," in Laser-based Micro- and Nanopackaging and Assembly V, edited by Wilhelm Pfleging, Yongfeng Lu, Kunihiko Washio, Jun Amako, Willem Hoving, Proceedings of SPIE Vol. 7921 (SPIE, Bellingham, WA, 2011) Article CID Number.

ISSN 0277-786X

ISBN 9780819484581

Published by

SPIE

P.O. Box 10, Bellingham, Washington 98227-0010 USA

Telephone +1 3606763290 (Pacific Time) · Fax +1 3606471445

SPIE.org

Copyright (C) 2011, Society of Photo-Optical Instrumentation Engineers

Copying of material in this book for internal or personal use, or for the internal or personal use of specific clients, beyond the fair use provisions granted by the U.S. Copyright Law is authorized by SPIE subject to payment of copying fees. The Transactional Reporting Service base fee for this volume is $\$ 18.00$ per article (or portion thereof), which should be paid directly to the Copyright Clearance Center (CCC), 222 Rosewood Drive, Danvers, MA 01923. Payment may also be made electronically through CCC Online at copyright.com. Other copying for republication, resale, advertising or promotion, or any form of systematic or multiple reproduction of any material in this book is prohibited except with permission in writing from the publisher. The CCC fee code is 0277-786X/11/ \$18.00.

Printed in the United States of America.

Publication of record for individual papers is online in the SPIE Digital Library.

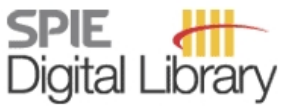

SPIEDigitalLibrary.org

Paper Numbering: Proceedings of SPIE follow an e-First publication model, with papers published first online and then in print and on CD-ROM. Papers are published as they are submitted and meet publication criteria. A unique, consistent, permanent citation identifier (CID) number is assigned to each article at the time of the first publication. Utilization of CIDs allows articles to be fully citable as soon they are published online, and connects the same identifier to all online, print, and electronic versions of the publication. SPIE uses a six-digit CID article numbering system in which:

- The first four digits correspond to the SPIE volume number.

- The last two digits indicate publication order within the volume using a Base 36 numbering system employing both numerals and letters. These two-number sets start with 00, 01, 02, 03, 04, $05,06,07,08,09,0 A, 0 B \ldots 0 Z$, followed by 10-1Z, 20-2Z, etc.

The CID number appears on each page of the manuscript. The complete citation is used on the first page, and an abbreviated version on subsequent pages. Numbers in the index correspond to the last two digits of the six-digit CID number. 


\section{Contents}

vii Conference Committee

ix Introduction

xi Laser based manufacturing of shunt lines for OLED lighting (Invited Paper) (Green Photonics Award Presentation) (Abstract-only) [7921-09]

M. Ruske, H. Schwab, Philips Technologie GmbH (Germany)

\section{LASE PLENARY SESSION}

$792102 \quad$ Microfabrication by optical tweezers [7921-102]

R. Ghadiri, T. Weigel, C. Esen, A. Ostendorf, Ruhr-Univ. Bochum (Germany)

\section{DIRECT-WRITE PROCESSING AND SURFACE MODIFICATION}

792104 Laser forward transfer for digital microfabrication (Invited Paper) [7921-02]

A. Piqué, H. Kim, R. Auyeung, A. Birnbaum, N. Charipar, K. Metkus, S. Mathews, U.S. Naval Research Lab. (United States)

792105 Formation of Si and Ge films and micropatterns by wet process using laser direct writing method [7921-03]

A. Watanabe, Tohoku Univ. (Japan)

WELDING, BONDING, BRAZING

$792107 \quad$ Extending the process limits of laser polymer welding with high-brilliance beam sources (recent status and prospects of POLYBRIGHT) (Invited Paper) [7921-05]

A. Olowinsky, A. Boglea, Fraunhofer-Institut für Lasertechnik (Germany)

792108 The effect of a homogenizing optic on residual stresses and shear strength of laser brazed ceramic/steel-joints [7921-06]

I. Südmeyer, M. Rohde, H. Besser, M. Grein, B. Liesching, J. Schneider, Karlsruhe Institute of Technology (Germany)

792109 Laser micro joining of thin metal films on flexible substrates for mechanical and electrical connections [7921-07]

M. Ehrhardt, K. Zimmer, Leibniz-Institut für Oberflächenmodifizierung e.V. (Germany)

7921 OA Laser welding assembling of an implantable bio-medical device: investigation of temperature field [7921-31]

Y. Lin, G. Jiang, J. L. Calderon, Alfred E. Mann Foundation for Scientific Research (United States) 


\section{ADDITIVE MANUFACTURING AND ADVANCED DEPOSITION PROCESSES}

7921 OC Strategy of fabrication of complex shape parts based on the stability of single laser melted track [7921-10]

I. Yadroitsev, I. Yadroitsava, I. Smurov, Ecole Nationale d'Ingénieurs de Saint-Etienne (France)

7921 OD Optical monitoring of heat processes in selective laser melting [7921-11]

M. Doubenskaia, M. Pavlov, Yu. Chivel, Ecole Nationale d'Ingénieurs de Saint-Etienne (France)

$7921 \mathrm{OE} \quad$ Laser-assisted synthesis of diamond crystals in open air through vibrational excitation of precursor molecules [7921-12]

Z. Q. Xie, Y. S. Zhou, X. N. He, Y. Gao, J. B. Park, T. Guillemet, Y. F. Lu, Univ. of Nebraska-Lincoln (United States)

7921 OF Diameter modulation of carbon nanotubes by rapid temperature modulation in laser-assisted chemical vapor deposition [7921-13] M. Mahjouri-Samani, Y. S. Zhou, W. Xiong, Y. Gao, M. Mitchell, Y. F. Lu, Univ. of Nebraska-Lincoln (United States)

\section{LASER MICRO-STRUCTURING AND MODIFICATION}

$7921 \mathrm{OH} \quad 3 \mathrm{D}$ adaptive spatio-temporal control of laser-induced refractive index changes in optical glasses (Invited Paper) [7921-15]

R. Stoian, Lab. Hubert Curien, CNRS, Univ. de Lyon, Univ. Jean Monnet (France);

G. Cheng, Xi'an Institute of Optics and Precision Mechanics (China); C. Mauclair, Lab. Hubert Curien, CNRS, Univ. de Lyon, Univ. Jean Monnet (France); A. Mermillod-Blondin, Max-Born-Institut für Nichtlineare Optik und Kurzzeitspektroskopie (Germany); K. Mishchik, E. Audouard, Lab. Hubert Curien, CNRS, Univ. de Lyon, Univ. Jean Monnet (France); A. Rosenfeld, I. V. Hertel, Max-Born-Institut für Nichtlineare Optik und Kurzzeitspektroskopie (Germany)

7921 Ol Laser selective patterning of ITO on flexible PET for organic photovoltaics [7921-27]

S. Xiao, B. Gröger, S. A. Fernandes, A. Ostendorf, Ruhr-Univ. Bochum (Germany)

7921 0J Laser-chemical finishing of micro forming tools [7921-17]

A. Stephen, C. Gerhard, F. Vollertsen, Bremer Institut für angewandte Strahltechnik GmbH (Germany)

\section{LASER NANO-STRUCTURING AND MACHINING}

7921 OK High aspect ratio taper-free micro and nano-channel fabrication in glass with ultrafast nondiffracting Bessel beams (Invited Paper) [7921-18]

F. Courvoisier, M. K. Bhuyan, M. Jacquot, P. A. Lacourt, R. Salut, L. Furfaro, J. M. Dudley, FEMTO-ST Institute, CNRS, Univ. de Franche-Comté (France)

7921 OL Nanoprocessing of glass and PMMA by means of near-infrared sub-15 femtosecond laser pulses [7921-19]

H. Zhang, M. Straub, K. König, M. Afshar, D. Feili, H. Seidel, Saarland Univ. (Germany) 
7921 OM Realization of high-performance optical element by optical near-field etching (Invited Paper) [7921-20]

K. Hirata, Sigma Koki Co., Ltd. (Japan)

7921 ON Highly efficient diffractive beam splitters surface-structured on submicron scale using deep-UV laser interference lithography [7921-21]

J. Amako, D. Sawaki, E. Fujii, Seiko Epson Corp. (Japan)

\section{BATTERIES AND THIN FILM STRUCTURING}

$792100 \quad \mathrm{LiCOO}_{2}$ texturing by laser induced forward transfer for printed microbatteries (Invited Paper) [7921-22]

A. C. Atre, C. B. Arnold, Princeton Univ. (United States)

$7921 \mathrm{OP} \quad$ Laser processing of $\mathrm{SnO}_{2}$ electrode materials for manufacturing of 3D micro-batteries [7921-23]

R. Kohler, J. Proell, S. Ulrich, Karlsruhe Institute of Technology (Germany); M. Przybylski, ATL Lasertechnik GmbH (Germany); W. Pfleging, Karlsruhe Institute of Technology (Germany)

$7921 \mathrm{OQ}$ Laser modification and characterization of Li-Mn-O thin film cathodes for lithium-ion batteries [7921-24]

J. Pröll, R. Kohler, C. Adelhelm, M. Bruns, M. Torge, S. Heißler, Karlsruhe Institute of Technology (Germany); M. Przybylski, ATL Lasertechnik GmbH (Germany); C. Ziebert, W. Pfleging, Karlsruhe Institute of Technology (Germany)

7921 OR Laser selective thin film structuring with different wavelengths [7921-25]

K. Du, P. Shi, EdgeWave GmbH (Germany)

\section{PHOTOVOLTAICS/ENERGY DEVICES: JOINT SESSION WITH CONFERENCE 7920}

7921 OS Recent status and prospects of the EU-funded ALPINE project (Invited Paper) [7921-26] S. Selleri, A. Cucinotta, F. Poli, E. Coscelli, D. Passaro, Univ. degli Studi di Parma (Italy); L. Leick, NKT Photonics A/S (Denmark); Y. Hernandez, Multitel A.S.B.L. (Belgium); V. Bermudez, NEXCIS (France); E. Zibik, N. Lichtenstein, Oclaro, Inc. (Switzerland); E. Lotter, Zentrum für Sonnenenergie- und Wasserstoff-Forschung (Germany); A. Bosio, Solar System \& Equipment (Italy); D. Polverini, European Commission Joint Research Ctr. (Italy)

7921 OT Change of electrical properties of CIGS thin-film solar cells after structuring with ultrashort laser pulses [7921-28]

A. Wehrmann, H. Schulte-Huxe, M. Ehrhardt, D. Ruthe, K. Zimmer, Leibniz-Institut für Oberflächenmodifizierung e.V. (Germany); A. Braun, S. Ragnow, Solarion AG (Germany)

7921 OU Laser processing of organic photovoltaic cells with a roll-to-roll manufacturing process (Invited Paper) (Green Photonics Award Paper) [7921-29]

T. Petsch, J. Haenel, M. Clair, B. Keiper, C. Scholz, 3D-Micromac AG (Germany)

7921 OV Multi-spot laser processing of crystalline solar cells [7921-30]

O. Haupt, V. Schütz, U. Stute, Laser Zentrum Hannover e.V. (Germany)

Author Index 
Downloaded From: https://www.spiedigitallibrary.org/conference-proceedings-of-spie on 26 Apr 2023

Terms of Use: https://www.spiedigitallibrary.org/terms-of-use 


\title{
Conference Committee
}

\author{
Symposium Chairs
}

Friedhelm Dorsch, TRUMPF GmbH \& Company KG (Germany)

Alberto Piqué, U.S. Naval Research Laboratory (United States)

Symposium Cochairs

Donald J. Harter, IMRA America, Inc. (United States)

Peter R. Herman, University of Toronto (Canada)

Program Track Chairs

Henry Helvajian, The Aerospace Corporation (United States)

James S. Horwitz, U.S. Department of Energy (United States)

Conference Chairs

Wilhelm Pfleging, Karlsruhe Institute of Technology (Germany)

Yongfeng Lu, University of Nebraska-Lincoln (United States)

Kunihiko Washio, Paradigm Laser Research Ltd. (Japan)

Conference Cochairs

Jun Amako, Seiko Epson Corporation (Japan)

Willem Hoving, XiO Photonics B.V. (Netherlands)

Program Committee

Friedrich G. Bachmann, LUMERA LASER GmbH (Germany)

Ramona Eberhardt, Fraunhofer-Institut für Angewandte Optik und Feinmechanik (Germany)

Bo Gu, IPG Photonics Corporation (United States)

Duncan P. Hand, Heriot-Watt University (United Kingdom)

Minghui Hong, National University of Singapore (Singapore)

Sybille Hopman, Fraunhofer-Institut für Solare Energiesysteme (Germany)

Lan Jiang, Beijing Institute of Technology (China)

Nam Seong Kim, EO Technics Company, Ltd. (Korea, Republic of)

Sonja M. Kittel, Robert Bosch GmbH (Germany)

Rainer Kling, Laser Zentrum Hannover e.V. (Germany)

Udo Klotzbach, Fraunhofer-Institut für Werkstoff- und Strahltechnik (Germany)

Thomas Klotzbücher, Institut für Mikrotechnik Mainz GmbH (Germany) 
Xinbing Liu, Panasonic Technologies Company (United States)

Tomoaki Matsushima, Panasonic Electric Works Company, Ltd. (Japan)

Marius Przybylski, ATL Lasertechnik GmbH (Germany)

Yasu Osako, Electro Scientific Industries, Inc. (United States)

Roberto Osellame, Istituto di Fotonica e Nanotecnologie, CNR, Politecnico di Milano (Italy)

Andreas Ostendorf, Ruhr-Universität Bochum (Germany)

Koji Sugioka, RIKEN (Japan)

Akira Watanabe, Tohoku University (Japan)

Xianfan Xu, Purdue University (United States)

Session Chairs

LASE PLENARY SESSION

Friedhelm Dorsch, TRUMPF GmbH \& Company KG (Germany)

Alberto Piqué, U.S. Naval Research Laboratory (United States))

1 Direct-write Processing and Surface Modification

Craig B. Arnold, Princeton University (United States)

2 Welding, Bonding, Brazing

Kunihiko Washio, Paradigm Laser Research Ltd. (Japan)

3 Additive Manufacturing and Advanced Deposition Processes

Willem Hoving, XiO Photonics B.V. (Netherlands)

4 Laser Micro-Structuring and Modification

Jun Amako, Seiko Epson Corporation (Japan)

$5 \quad$ Laser Nano-Structuring and Machining

Friedrich G. Bachmann, LUMERA LASER GmbH (Germany)

$6 \quad$ Batteries and Thin Film Structuring

Wilhelm Pfleging, Karlsruhe Institute of Technology (Germany)

$7 \quad$ Photovoltaics/Energy Devices: Joint Session with Conference 7920

Yongfeng Lu, University of Nebraska-Lincoln (United States) 


\section{Introduction}

Today, leading designs and applications are progressively being based on microand nanosystem technologies because of their novel and significantly improved physical, chemical, and biological properties and phenomena. Advanced laserbased micro- and nanopackaging and assembly is in strong demand by hightech industries to be used for specialized prototypes and high-throughput devices with micro- and nanostructures to realize electronic, photonic, mechanical, fluidic, chemical, and biological functionalities. However, the realization of such devices or functional prototypes imposes new challenges for patterning, packaging, and assembly.

Miniaturization of the functional devices and systems significantly increases the complexity of their design and fabrication. Due to the continually increasing complexity of device structures, processing needs for a wide variety of materials are required, leading to new applications and fields of research. However, these new requirements impose new challenges in developing appropriate assembly and packaging technologies. The laser-induced modification of material properties on the micro- or nanoscale becomes increasingly important for some applications (e.g. photovoltaics, batteries). On one hand, undesirable material and surface modifications, such as chemical or heat-affected structural changes, must be avoided. On the other hand, laser-assisted processes, such as annealing, doping, and refractive index changes, can be used to obtain new and advanced materials and functionalities for larger areas as well as those on the micrometer and nanometer scale. There is also a strong demand to transfer these novel laser-based processing technologies to industry-relevant applications with high efficiency and throughput.

The Laser-Based Micropackaging conference series was established in 2002. In 2007, the conference was renamed "Laser-Based Micro- and Nano-Packaging and Assembly (LBMP)" to reflect the increasing relevance of nanometer-scaled structures. The aim of this conference is to bring together scientists and engineers working on application-oriented aspects of laser-based micro- and nanopackaging for electronic, photonic, mechanical, chemical, biological, bioactive, or biocompatible devices, including MEMS/bio-MEMS, MOEMS, and OLEDs. Because of the great economical demand, material processing is playing an increasingly important role in current and future LBMP conferences, along with new "green technologies" such as photovoltaics and advanced energy storage systems. Two speakers at the LBMP conference received the Green Photonics Award of SPIE which underlines the strong relevance of the LBMP conference for future oriented and ecological applications.

The LBMP-V conference was held January 25-27 as part of LASE 2011 at Photonics West in San Francisco, California. LBMP-V was comprised of 27 oral presentations 
by speakers from France, Italy, Japan, Switzerland, Germany, and the United States. The presentations represented a number of topics including: laser welding and joining, ultrafast laser, advanced laser-assisted deposition and synthesis, laser micro- and nanostructuring and modification, micro- and nanomachining, batteries and thin films, direct-write processing and surface modification, and photovoltaics. The photovoltaics session was jointly organized with Conference 7920: Laser Applications in Microelectronic and Optoelectronic Manufacturing XVI (LAMOM XVI).

We would like to express our deepest gratitude to the Program Committee members and the SPIE technical staff for their great efforts during the planning and organization of LBMP-V. We would also like to thank the invited speakers and those who presented papers for their contribution to the success of the conference. All the manuscripts were peer reviewed in order to publish highquality conference proceedings.

Wilhelm Pfleging

Yongfeng Lu Kunihiko Washio 


\title{
Laser based manufacturing of shunt lines for OLED lighting
}

\author{
Manfred Ruske, Holger Schwab, Philips Technologie GmbH, Global Business Unit OLED, Aachen, \\ Germany
}

\section{EXTENDED ABSTRACT}

OLED lighting is a new player in the arena of high efficiency, long lived light sources. In contrast to inorganic LED, OLED is a technology to realise large area light sources. The base technology is already in wide use for displays like mobile phones or PDA's. One of the main attention points in this technology is the need to realise large are light sources by at the same time maintaining low cost as we have to compete with classical light sources. The main cost driver in OLED lighting is the substrate compromising a glass plate, a transparent conductive oxide (TCO) and a metal grid to support current distribution in the area. These substrates are manufactured using passive matrix display technology. The glass plate is coated with a layer of the conductive oxide and a second layer of the metal which is then sequentially structured again using photo lithography. The TCO acts as transparent anode of the OLED device. In subsequent processes, the organic layer stack and a metal cathode are deposited via thermal evaporation in vacuum. Afterwards, the device is encapsulated with cavity glass.

In collaboration with the Fraunhofer ILT group we have developed a new technology to realise metal shunt lines on a transparent electrode. This process makes use of a pulsed laser system used to melt and partially vaporise metal from a carrier foil. This metal is transferred onto the OLED substrate. In order to assure good line definition, a shadow mask defining the deposition area and reducing overspray is placed between the carrier foil and the glass substrate. Alternatively, the carrier foil is structured in such a way that it acts as a shadow mask by itself (figure 1). Using this technology it is possible to realise shunt lines of copper and aluminium with a conductivity close to bulk at high transfer rates.

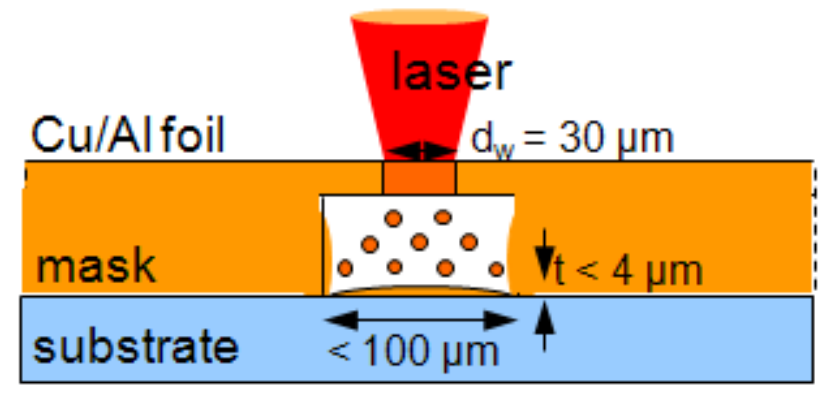

Figure 1 Working principle for the metal transfer process using a carrier foil with structures that act as a mask

Achievable metal line widths are below 100 microns, which is sufficient for OLED lighting applications. It is possible to produce overlapping and crossing lines as used in a typical grid to improve the current distribution. It is possible to increase the conductivity of metal lines by depositing multiple layers. Processing speeds up to about $2.5 \mathrm{~m} / \mathrm{min}$ were realised with optimized power and pulse repetition rate. For testing the process with regard to industrialization, various process parameters were varied and the influence on the quality of the deposited metal lines was tested. Typical thicknesses for the shadow mask are in the range 50 microns, and a variation of 10 microns in both directions has no significant influence. Slit widths between 60 and 120 microns were tested for the shadow mask without a negative impact on the specific resistivity of the deposited lines. Also the results for a $5 \%$ variation in power or scan speed (without changing the other parameters) were within the tolerance range. However, it is important to have a precise alignment between the laser focus and the center of the mask slits for high quality results.

The work on the process will be continued. One of the remaining challenges is the production of structured carrier foils which simultaneously act as carrier and mask. This work has received funding from Germany's Federal Ministry for Education and Research (BMBF) within the „OPAL 2008“ project. 
Downloaded From: https://www.spiedigitallibrary.org/conference-proceedings-of-spie on 26 Apr 2023

Terms of Use: https://www.spiedigitallibrary.org/terms-of-use 